ОРИГИНАЛНИ СТАТИИ

ORIGINAL ARTICLES

\title{
ПРОСПЕКТИВНО ПРОУЧВАНЕ НА НЕЖЕЛАНИ ЛЕКАРСТВЕНИ РЕАКЦИИ \\ ПРИ БЪЛГАРСКА ПОПУЛАЦИЯ ОТ ПАЦИЕНТИ С ВЪЗПАЛИТЕЛНИ СТАВНИ ЗАБОЛЯВАНИЯ, ПРОВЕЖДАЛИ ЛЕЧЕНИЕ С БИОЛОГИЧНИ ЛЕКАРСТВЕНИ ПРОДУКТИ
}

\author{
И. Първова ${ }^{1}$, А. Рангелов ${ }^{2}$, Е. Христов ${ }^{2}$, Р. Рашков ${ }^{1}$, И. Гетов ${ }^{3}$, С. Огнянов ${ }^{2}$ \\ 'Клиника по ревматология, УМБАЛ "Свети Иван Рилски”, Катедра „Вътрешни болести“, Медицински университет - София \\ Факултет по химия и фрармация, Софийски университет “Св. Климент Охридски” - София \\ зКатедра по социална фармация, Фармацевтичен факултет, Медицински университет - София

\section{PROSPECTIVE STUDY OF ADVERSE DRUG REACTIONS IN A BULGARIAN POPULATION OF PATIENTS WITH INFLAMMATORY JOINT DISEASES TREATED WITH BIOLOGICAL MEDICINAL PRODUCTS}

\author{
I. Parvova', A. Rangelov², E. Hristov' ${ }^{2}$ R. Rashkov', I. Getov ${ }^{3}$, S. Ognianov²
}

${ }^{1}$ Clinic of Rheumatology, University Hospital "Sveti Ivan Rilski”, Department of Internal Medicine, Medical University - Sofia ${ }^{2}$ Faculty of Chemistry and Pharmacy, Sofia University "Sveti Kliment Ohridski" - Sofia ${ }^{3}$ Department of Social Pharmacy, Faculty of Pharmacy, Medical University - Sofia

\begin{abstract}
Резюме. Целта е да се анализират нежеланите лекарствени реакции (НЛР) при българска популация пациенти с възпалителни ставни заболявания, които отговарят на изискванията да провеждат лечение с биологични лекарствени продукти (БЛП). Описва се едноцентрово, обсервационно, открито, проспективно, неинтервенционално, фрармакоепидемиологично проучване на клинични серии от случаи на НЛР при българска популация пациенти с ревматоиден артрит (РА), анкилозиращ спондилит (АС) и псориатичен артрит (ПсА) на лечение с БЛП през периода март 2015 г.-октомври 2016 г. Проучването е осъществено по протокол и след подписано информирано съгласие. Пациентите провеждат лечение със: etanercept, adalimumab, golimumab, certolizumab pegol, rituximab. Задължително условие е да няма предхождащо лечение с БЛП. Статистическите анализи са направени с пакет SPSS версия 16.0. Скринирани са 53 пациенти, 5 не отговарят на включващите критерии; 47 включени, от тях 5 отпадат в хода на проучването, анализирани 42. Разпределение по заболявания: $P A-40,5 \%$ $(n=17), \Pi c A-19 \%$ ( $n=8), A C-40,5 \%(n=17)$. Жени - 52\% ( $n=22)$, мъже - 48\% ( $n=20)$. При 76\% от пациентите лечението е с adalimumab и etanercept. При $17 \%$ от пациентите $(n=7)$ биологичното лечение е спряно поради изява на сериозни НЛР, при 3 от тях - с 3-та степен на тежест, при 4 - c 4 степен. Най-голям относителен дял заемат НЛР със степен на тежест 1 и 2, като с 1 степен са 63\%. Общият брой на съобщените и потвърдени НЛР е 160. От тях 3 НЛР отговарят на дефиницията за SUSAR; неочаквани - 30; подозирани - 127. Общата честота на НЛР в иялото проспективно проучване се измерва на 3,80 НЛР/пациент, като най-висок е този дял при АC - 4,35 НЛР/пациент. Установява се много висока честота на НЛР, несъответно по-висока в сравнение с предрегистрационните данни за анализираните БЛП. Най-честата причина за преустановяване на биологичната терапия при болните с възпалителни ставни заболявания е изявата на НЛР.
\end{abstract}

Ключови думи: възпалителни ставни заболявания, нежелани лекарствени реакции, биологично лечение, проспективно проучване

Abstract. To analyze Adverse Drug Reactions (ADRs) in a Bulgarian population of patients with inflammatory joint diseases who are eligible to receive treatment with biological medicinal products (BMP). A single-center, observational, open-label, prospective, non-interventional, pharmacoepidemiological study of clinical cases 
of ADRs in a Bulgarian population of patients with rheumatoid arthritis (RA), ankylosing spondylitis (AS) and psoriatic arthritis (PSA), treated with BMP between March 2015 and October 2016. The study was conducted on a protocol basis and after signed informed consent. Patients were treated with: Etanercept, Adalimumab, Golimumab, Certolizumab pegol, Rituximab. It was a prerequisite not to have previous BMP treatment. The statistical analysis was made with SPSS version 16.0. 53 patients were screened, 5 did not meet the inclusion criteria; 47 enrolled, 5 withdrawn from the study, 42 analyzed. Disease distribution: $R A-40.5 \%(n=17)$, PsA-19\% ( $n=8)$, AS-40.5\% ( $n=17)$. Women $-52 \%(n=22)$, men $-48 \%(n=20) .76 \%$ of the patients were treated with Adalimumab and Etanercept. In $17 \%$ of the patients $(n=7)$, biological treatment was discontinued due to serious ADRs. Three of them were grade 3 severity, 4 -grade 4 severity. The largest relative share was occupied by ADRs with grade 1 and 2 severity, whereas $63 \%$ of ADRs had grade 1 severity. The total number of reported and confirmed ADRs was 160. 3 ADRs meet the definition of SUSAR; 30 ADRs were unexpected; 127 ADRs were suspected. The overall incidence of $A D R$ in the entire prospective study was 3.80 ADR/patient, the highest being AS - 4.35 ADR/patient. We have established a very high incidence of ADRs that is inappropriately higher than pre-authorization data for the analyzed BMP. The most common cause of discontinuation of biological therapy in patients with inflammatory joint diseases is the onset of ADR.

Key words: inflammatory joint diseases, adverse drug reactions, biological treatment, prospective study

\section{ВъВЕДЕНИЕ}

За първи път биологичен лекарствен продукт (БЛП) с терапевтични показания за приложение в областта на ревматологията е разрешен за употреба по Централизирана процедура на 02.06.1998 г. - Mabthera, с международно непатентно наименование (INN) rituximab, с показания за лечение хронична лимфоцитна левкемия, неходжкинов лимфом и ревматоиден артрит [1]. От тогава досега разрешените за употреба БЛП, вкл. и подобни БЛП (биоподобни/biosimilar) с терапевтични показания за приложение в областта на ревматологията, са повече от 20 и масово навлизат в клиничната практика [2-6]. Предрегистрационните данни за безопасност и ефикасност са достатъчни за получаване на разрешение за употреба и пускане на пазара, въпреки че изследователската фаза е относителна кратка по време и включва малък брой пациенти. В пострегистрационния период интерес за изследователите и клиницистите представляват данните за терапевтичната ефективност, и то в сравнителен аспект, и най-вече данните за изява на нежелани лекарствени реакции.

\section{ЦЕл}

Първична цел е да проследим проспективно появата на нежелани лекарствени реакции (НЛР) и да направим обща оценка на лекарствената безопасност при българска популация от пациенти с възпалителни ставни заболявания, които ще провеждат лечение с БЛП, чрез активно търсене по предварително зададени критерии. Вторични цели: НЛР да бъдат анализирани по вид, честота

\section{INTRODUCTION}

A biological medicinal product (BMP) with therapeutic indications for use in the area of rheumatology was authorized for the first time under a centralized procedure on 02.06.1998 - Mabthera, with international nonproprietary name (INN) Rituximab. It was authorized for the following indications - chronic lymphocytic leukemia, non-Hodgkin lymphoma, and rheumatoid arthritis [1]. Since then, there have been more than 20 authorized BMPs, including similar BMPs (biosimilars) with therapeutic indications for rheumatic diseases, and they are becoming more and more widespread in clinical practice [2-6]. Pre-authorization safety and efficacy data are sufficient to obtain marketing authorization and distribution authorization, although the research phase is relatively short in time and includes a small number of patients. In the post-authorization period, the therapeutic efficacy data are of interest to both investigators and clinicians, especially in terms of comparison, particularly the data of onset of adverse drug reactions.

\section{AIM}

Our primary aim is to follow the onset of adverse drug reactions (ADRs) prospectively and make a general assessment of drug safety in a Bulgarian population of patients with inflammatory joint diseases, who will be treated with BMPs, through active search according to preset criteria. Secondary aims: analyze ADRs by type, incidence, and degree of severity; assess 
и степен на тежест; да се оценят спазването на стандартите за лечение на възпалителните ставни заболявания; да се анализират причините за неуспех от лечението като: липса на къмплайънс, изява на НЛР, вкл. сериозни НЛР, и други.

\section{МАТЕРИАЛ И МЕТОДИ}

Дизайн на проучването: едноцентрово, обсервационно, открито, проспективно, неинтервенционално, фрармакоепидемиологично проучване на клинични серии от случаи на изява на НЛР при българска популация пациенти с ревматоиден артрит, анкилозиращ спондилит и псориатичен артрит, провеждащи лечение с биологични лекарствени продукти. Проучването е проведено в периода март 2015 г.-октомври 2016 г., по предварително изготвен протокол. Всички участници са подписали информирано съгласие. Протоколът и информираното съгласие са изготвени в съответствие с изискванията на ЗЛПХМ, Закона за здравето при спазване на етичните принципи, заложени в Декларацията от Хелзинки, и Ръководството за добра клинична практика [7-11]. Проучването е съобразено и с изследователските практики, описани в Добра фармакоепидемиологична практика на Международното общество по фрармакоепидемиология (ISPE) [12].

Пациентите, включени в изпитването, трябва да имат едно от следните заболявания: ревматоиден артрит (РА), анкилозиращ спондилит (АС), псориатичен артрит (ПсА), и да са определени като подходящи за лечение с някои от следните лекарствени продукти по международни непатентни наименования (INN): etanercept, adalimumab, golimumab, certolizumab pegol, rituximab, включително със или без methotrexate.

Включващи критерии: Пациентите, включени в проучването, трябва да отговарят на всички от следните критерии: 1. Мъже и жени на възраст $\geq$ 18 години; 2. Мъже и жени със сигурна диагноза: ревматоиден атрит - наличие на 4 и повече критерия в съответствие със стандартите, утвърдени от American College of Rheumatology (ACR) [13-16], или анкилозиращ спондилит - наличие на рентгенологични данни за сакроилиит и поне 1 клиничен критерий, съгласно Модифицираните критерии на ACR [17], или псориатичен артрит - наличие на възпалително ставно заболяване и 3 или повече точки, съгласно Класификационните критерии за псориатичен артрит (Classification for Psoriatic Arthritis criteria - CASPAR) [18]; 3. Да не са провеждали предхождащо лечение с БЛП - etanercept, compliance with the standards of treatment of inflammatory joint diseases; analyze the reasons for treatment failure, such as lack of compliance, the onset of ADRs, including serious ADRs, etc.

\section{MATERIALS AND METHODS}

Study design: a single-center, observational, open-label, prospective, non-interventional, pharmacoepidemiological study of clinical cases of ADRs in a Bulgarian population of patients with rheumatoid arthritis, ankylosing spondylitis and psoriatic arthritis, treated with biological medicinal products. The study was conducted from March 2015 to October 2016, according to a predefined protocol. All participants signed an informed consent form. The protocol and the informed consent were prepared according to the provisions of LMPHM and the Health Law, in compliance with the ethical principles set in the Declaration of Helsinki and Good Clinical Practice Guideline [7-11]. The study also complies with the research practices described in the Good Pharmacopoeiological Practice of the International Society for Pharmacoepidemiology (ISPE) [12].

Patients included in the study must have one of the following diseases: rheumatoid arthritis (RA), ankylosing spondylitis (AS) and psoriatic arthritis (PsA), and be assessed as eligible for treatment with one of the medicinal products with the following International Nonproprietary Names (INN): Etanercept, Adalimumab, Golimumab, Certolizumab pegol, Rituximab, including with or without Methotrexate.

Inclusion criteria: Patients included in the study must meet all of the following criteria: 1 . Men and women aged $\geq 18$; 2 . Men and women with a definite diagnosis: Rheumatoid arthritis - the presence of 4 or more criteria according to the standards established by the American College of Rheumatology (ACR) [13-16], or Ankylosing spondylitis - the presence of radiographic data of sacroiliitis and at least one clinical criteria according to the modified ACR criteria [17], or Psoriatic arthritis - the presence of inflammatory joint disease and three or more points, according to the psoriatic arthritis classification criteria (Classification for Psoriatic Arthritis criteria - CASPAR) [18]; 3. No prior treatment with BMPs - Etanercept, Adalimumab, Golimumab, Certolizumab pegol, Rituximab. An exception to this requirement is acceptable for patients, who will 
adalimumab, golimumab, certolizumab pegol, rituximab. Изключение от това изискване е допустимо за пациенти, които ще провеждат лечение с rituximab. Те обичайно са лекувани преди това с един или повече инхибитори на TNF- $\alpha$, но са имали незадоволителен терапевтичен отговор и при тях се назначава биологична терапия от втора линия; 4. Да не са провеждали лечение с биоподобни лекарствени продукти; 5. Да отговарят на критериите на НЗОК за лечение с БЛП [19]; 6. Подписано и датирано информирано съгласие, че пациентите са запознати с всички аспекти на проучването.

Изключващи критерии: 1. Отказ от подписване на информирано съгласие; 2. Възраст под 18 години; 3. Пациенти с РА, АС или ПсА, провеждали предхождащо лечение с БЛП; 4. Пациенти с РА, АС или ПсА, провеждали предхождащо лечение с биоподобни лекарствени продукти; 5. Несъответствие с критериите на НЗОК за лечение с БЛП. 6. Оттегляне на вече подписано информирано съгласие.

Скриниращата визита се провежда след подписване на информирано съгласие и до 4 седмици от започване на биологичното лечение. Всеки пациент получава анкетна карта за регистриране на НЛР и инструкции за нейното попълване. Проучването включва 2 проследяващи визити през 6 месеца. За целите на проспективното проучване са разработени Клинични карти за пациента, в зависимост от това на какъв вид лечение ще бъде всеки един от тях. Клиничните (анкетни) карти са изработени в съответствие с КХП на съответния лекарствен продукт и съдържат данни за подозираните НЛР така, както са установени в предрегистрационния период.

Оценката на безопасността е направена чрез анализ на събраната информация, получена от анкетните карти на пациентите. Безопасността на биологичното лечение при всеки пациент бе проследявана през 6 месеца до 12-ия месец включително. Определихме големината на популацията и анализирахме получените данни за НЛР по брой пациенти, заболявания, демографски показатели и др. Проведохме анализ на епидемиологични данни и съотношения. Личните данни на пациентите, включени в това фрармакоепидемиологично проучване, са защитени. Всеки пациент можеше да оттегли съгласието си за участие в проучването по собствено желание по всяко време или да отпадне по преценка на изследователя.

Въвеждането на данните, тяхната първоначална обработка, графичното представяне и статистическите изчисления са направени със SPSS, версия 16.0. Използвахме следните ста- receive Rituximab. Usually, they have been previously treated with one or more TNFa inhibitors, but had an unsatisfactory therapeutic response and were given second-line biological therapy; 4. No previous treatment with biosimilar medicinal products; 5. Compliance with the National Health Insurance Fund (NHIF) criteria of BMP treatment [19] 6. Signed and dated Informed Consent Form evidencing that the patients are aware of all aspects of the study.

Exclusion criteria: 1. Refusal to sign the Informed Consent Form; 2. Age under 18; 3. Patients with RA, AS, or PsA, who have had prior treatment with BMPs; 4. Patients with RA, AS, or PsA, who have had prior treatment with biosimilar medicinal products; 5 . Non-compliance with the NHIF criteria of BMP treatment. 6. Withdrawal of already signed the Informed Consent Form.

The screening visit takes place after the signature of the Informed Consent Form, and each patient obtains an ADR registration questionnaire and the instructions of its completion up to 4 weeks as of the beginning of the biological treatment. The study includes two follow-up visits every six months. For the purposes of the prospective study, case report forms are developed depending on what kind of treatment each patient will have. The case report forms (questionnaires) are developed according to the SmPC of the respective medicinal product and contain data of the suspected ADRs, as they have been identified in the pre-registered period.

Safety assessment is done by analyzing the information collected from the case report forms of the patients. The safety of the biological treatment in each patient is followed every six months, up to the $12^{\text {th }}$ month, inclusive. We determined the size of the population and analyzed the ADR data by the number of patients, diseases, demographic parameters, etc. We conducted an analysis of epidemiological data and ratios. The personal data of the patients included in this pharmacoepidemiological study have been protected. Each patient can withdraw his/her consent to participate in the study by his/her own will at any time or withdraw at the discretion of the investigator.

Data entry, initial processing, graphic representation, and statistical calculations are made with SPSS version 16.0. We used the following statistical methods of empirical data processing: Descrip- 
тистически методи за обработване на емпирични данни: дескриптивен анализ - средна аритметична, мода, медиана като мярка на централната тенденция; стандартно отклонение; доверителен интервал; вариационен анализ на количествени променливи; Т-критерий на Student за сравняване на средни величини при нормално разпределение; метод на Clopper-Pearson.

\section{Резултати}

В проучването бяха скринирани общо 53 пациенти, допуснати за лечение с БЛП в периода 14 април 2015 г. - 28 май 2015 г. От общия брой скринирани, 5 пациенти получиха отказ за започване на лечение; 1 пациент почина преди получаване на разрешение за провеждане на биологично лечение. Общо 47 пациенти бяха включени в клиничното наблюдение след започнато лечение с БЛП. В хода на проучването 5 от скринираните пациенти и започнали биологично лечение бяха свалени от активно проследяване преди изтичане на едногодишния период на проспективното проучване поради следните причини: 1 пациент е с предшестващо биологично лечение с анти-TNF - не отговаря на заложените включващи критерии да не е провеждал лечение с БЛП; 1 пациент в хода на проучването оттегли информираното си съгласие и 3 пациенти не продължиха лечението след 6-ия месец поради причина, различна от изява на НЛР. Едногодишното наблюдение обхвана общо 42 пациенти, от които 20 мъже и 22 жени. Разпределението на пациентите по видове заболявания е представено на фиг. 1. Средна възраст на мъжете е 47,6 г., а на жените - 54,6 г.

В $17 \%$ от случаите $(n=7)$ биологичното лечение е спряно в хода на проспективното наблюдение поради изява на сериозни НЛР - фриг. 2. tive analysis - arithmetic mean, mode, median as a measure of the central trend; Standard deviation; Confidence interval; Variation analysis of quantitative variables; T-criteria of Student of comparing average values in normal distribution; Clopper-Pearson model.

\section{Results}

In this study, a total of 53 patients were screened and admitted to BMP treatment from 14 April 2015 to 28 May 2015. Out of the total number of the screened patients, 5 patients have been denied treatment; 1 patient died prior to the receipt of the authorization of the administration of biological treatment. A total of 47 patients were included in the clinical observation after the beginning of BMP treatment. In the course of the study, 5 of the patients, who were screened and started biological treatment, withdrew from the active follow-up prior to the expiry of the 1-year period of the prospective study for the following reasons: 1 patient had prior biological treatment with anti-TNF - he did not meet the preset inclusion criteria of absence of prior BMP treatment; 1 patient withdrew his Informed Consent Form in the course of the study, and 3 patients did not continue their treatment after the 6th month for any other reason, different from the onset of ADRs. The one-year observation included 42 patients - 20 men and 22 women. The distribution of the patients by type of disease is presented in Fig. 1. Men's average age is 47.6, and women's average age is 54.6 .

In $17 \%$ of the cases $(n=7)$, biological treatment was discontinued in the course of the prospective observation due to the onset of serious ADRs - Fig. 2.

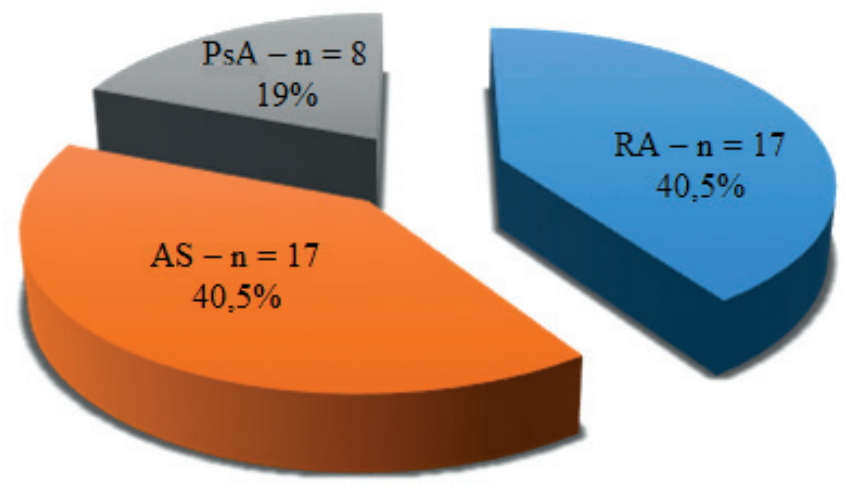

Фие. 1. Разпределение на пациентите по вид на възпалителното ставно заболяване

Fig. 1. Distribution of patients by type of inflammatory joint disease 


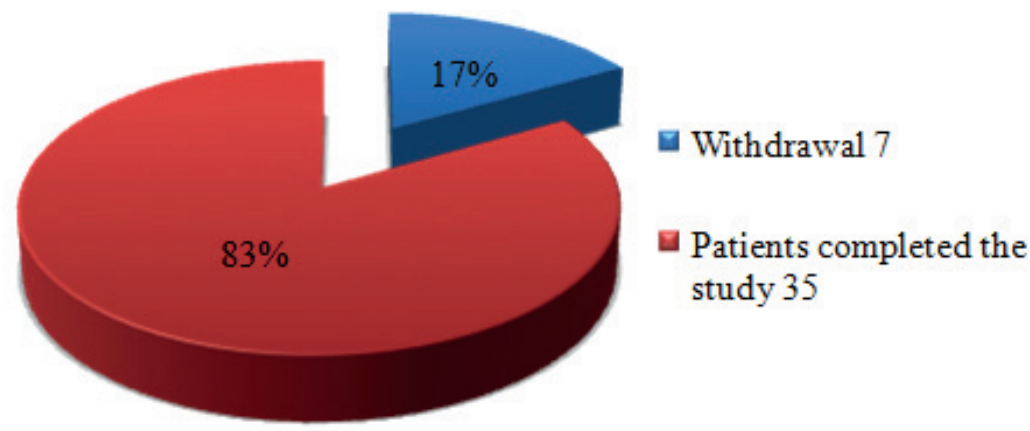

Фие. 2. Пациенти, отпаднали поради сериозни НЛР

Fig. 2. Patients withdrawn due to severe ADRs

Получените резултати показват висок относителен дял на случаите, при които биологичното лечение е преустановено - 25,5\% (от 47 пациенти 7 отпадат поради сериозни НЛР, 5 отпадат поради други причини).

Тежестта на установените сериозни НЛР е оценена по общите терминологични критерии за НЛР (Common Terminology Criteria for Adverse Events by National Cancer Institute - CTCAE version 4.03, June 14, 2010) [20]. 3 от НЛР са оценени като 3 степен на тежест, а останалите 4 като 4 степен на тежест.

Анализ на резултатите при пациенти с АC. Данните на пациентите са оценени по основни демографски показатели - възраст, пол, възрастови групи, вид на провежданото биологично лечение по лекарствен продукт, средна възраст на проследените пациенти. Групата с АС включва 18 пациенти - 15 (10 мъже и 5 жени) са наблюдавани и проследени за пълен едногодишен период. Всички пациенти са провели цикъл от 12-месечно лечение със съответния БЛП, с изключение на 1 пациент, при когото лечението е продължило само 6 месеца. При двама лечението е прекратено поради изява на сериозни НЛР. Анализът на демографските показатели показва, че мъжете са 2 пъти повече от жените, като това се наблюдава за всички възрастови групи. Средната възраст на проследяваните мъже и жени в групата с AC е изравнена - средната възраст на мъжете е 45,8 г., а на жените е 45,6 г. Във възрастовата група над 65 г. няма пациенти с AC (таблица 1).

Пациентите в групата с AC са провеждали лечение с 3 вида БЛП - etanercept, adalimumab и golimumab. Най-голям дял заема групата пациенти на лечение c adalimumab, докато само един пациент е на лечение c golimumab.

НЛР са систематизирани по системо-органната класификация по MedDRA, версия 12.0 [21],
The results show the relative share of the cases, in which the biological treatment was discontinued $25.5 \%$ (out of 47 patients, 7 withdrew due to severe ADRs, 5 withdrew for other reasons).

The severity of the identified serious ADRs was assessed according to the common terminology criteria for ADRs (Common Terminology Criteria for Adverse Events by National Cancer Institute - CTCAE version 4.03, June 14, 2010) [20]. Three ADRs were assessed with grade 3 severity, and the rest four ADRs had grade 4 severity.

Analysis of results in patients with AS. Patient data were assessed by basic demographic parameters - age, sex, age groups, type of biological treatment by medicinal product, the average age of the followed-up patients. The AS group included 18 patients - 15 were observed and followed up for a full 1-year period, of them ten men and five women. All patients had a 12-month treatment cycle with the respective BMP, except for one patient, who was treated for only 6 months. In two patients, the treatment was discontinued due to the onset of serious ADRs. The analysis of the demographic parameters shows that men are 2 times more than women, and this is observed in all age groups. The average age of the men and women in the AS group was equalized - men's average age is 45.8, and women's average age was 45.6. No patients with AS were included in the age group over 65 (Table 1).

The patients in the AS group received treatment with three types of BMP - Etanercept, Adalimumab, and Golimumab. The group of the patients treated with Adalimumab had the largest share, whereas there was only one observed patient treated with Golimumab.

ADRs are systematized according to MedDRA System Organ Class, version 12.0 [21]. Their inci- 
тяхното честотно разпределение е представено на фриг. 3, а тяхното типизиране - на фиг. 4. Общият брой на съобщените и потвърдени НЛР е 74. От тях сериозни НЛР (довели до отпадане от проучването) са 2, от които 1 НЛР отговаря на дефиницията за SUSAR, а втората попада в групата на подозираните; неочакваните са 9; а подозираните - 64 . dence distribution is presented in Fig. 3 and their typing is presented in Fig. 4. The total number of reported and confirmed ADRs was 74. Of them, there were 2 serious ADRs (leading to the withdrawal of the study), of which 1 ADR met the definition of SUSAR, and the second one fell into the group of suspected ADRs; there were nine unexpected ADRs and 64 suspected ADRs.

Таблица 1. Демографски данни на пациенти с АC

Table 1. Demographic data of patients with AS

\begin{tabular}{|c|c|c|c|}
\hline Parameters & Men & Women & Total \\
\hline Age $18-45$ years & $4(26.66 \%)$ & $3(13.33 \%)$ & $9(60.0 \%)$ \\
\hline Age $46-65$ years & $6(40.0 \%)$ & - & - \\
\hline Age $\uparrow 65$ years & - & $5(33.33 \%)$ & $15(100.0 \%)$ \\
\hline Number & $10(66.66 \%)$ & 45.6 & 45.7 \\
\hline Average & 45.8 & 53.0 & 53.0 \\
\hline Median & 53.0 & 53.0 & 35.0 \\
\hline Mode & 53.0 & 15.0 & 15.0 \\
\hline Standart deviation & 14.9 & & \\
\hline
\end{tabular}

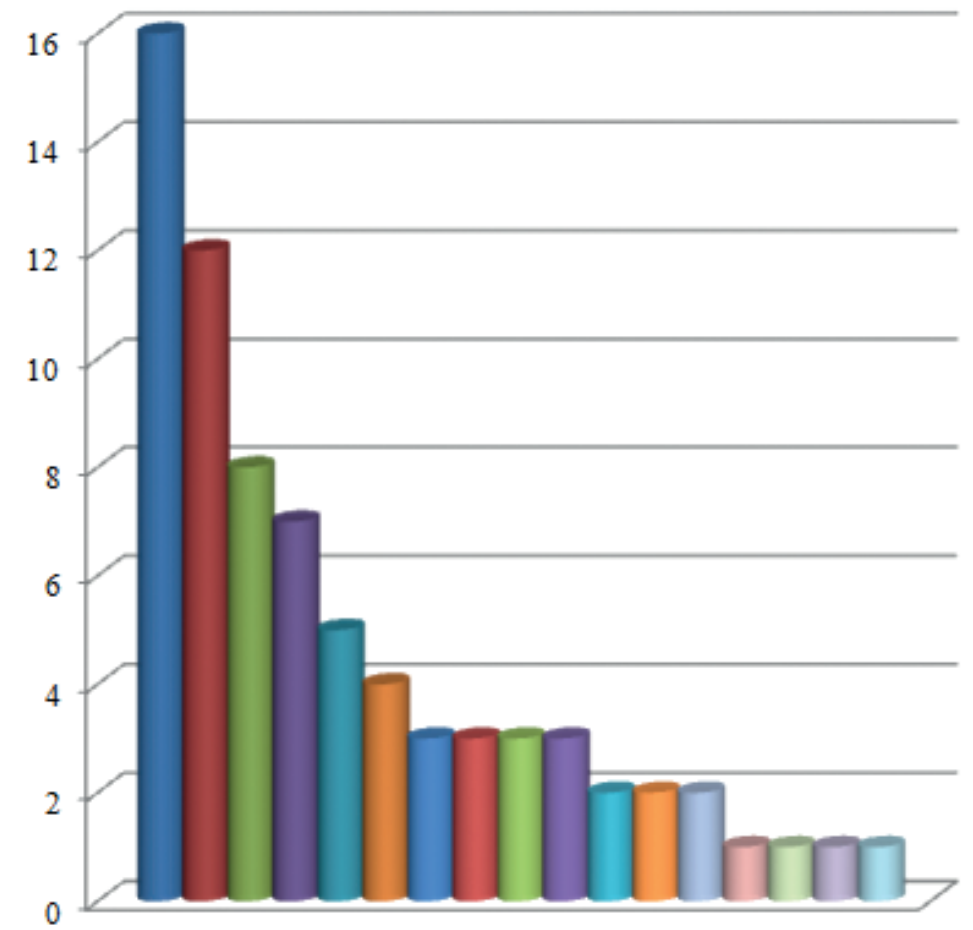

- Blood and lymphatic system disorders

" Infections and infestations

= General dis orders and administration site conditions

- Hepatobiliary disorders

" Psychiatric dis orders

= Metabolism and nutrition dis orders

= Skin and subcutaneous tis sue disorders

- Gastrointestinal disorders

|" Vascular disorders

m Investigations

= Cardiac dis orders

" Respiratory, thoracic and mediastinal

disorders

" Ear and labyrinth disorders

" Eye dis orders

" Nervous system dis orders

" Injury, poisoning and complications resulting from interventions

Musculoskeletal disorders

Фие. 3. НЛР, систематизирани по системо-органната класификация по MedDRA, версия 12.0

Fig. 3. ADRs systematized according to MedDRA System Organ Class, version 12.0 


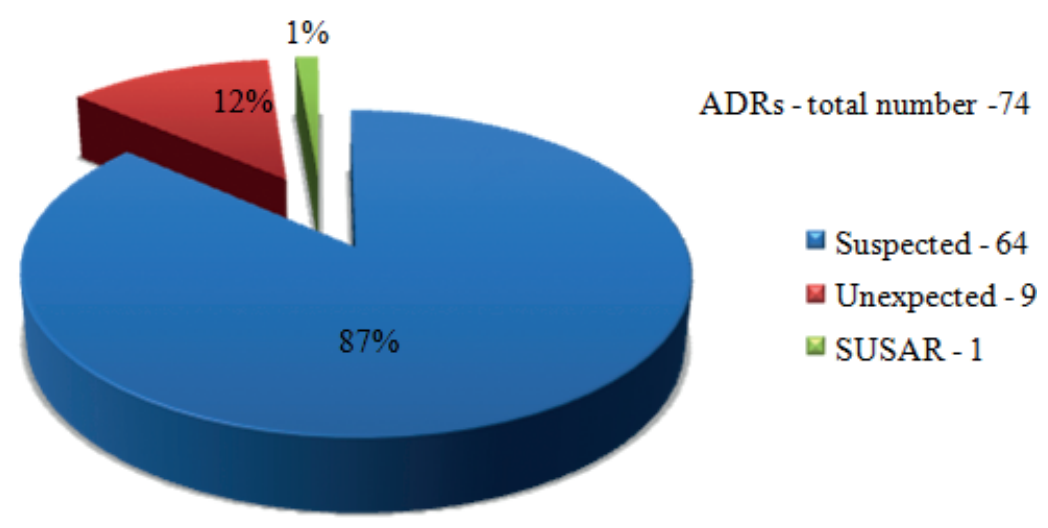

\section{Фие. 4. Видове НЛP}

Fig. 4. Types of ADRs

Оценихме връзката на НЛР с провежданото лечение и установихме: сигурна връзка (каузална връзка - причинно-следствена връзка) - 5; вероятна връзка - лекарството се свързва с появата на НЛР, но липсва възпроизводимост на лабораторните данни - 51; възможна връзка съществува временна връзка между лекарството и НЛР - 18; съвпадение - НЛР се появява по време на прием на лекарството, но причината е друга - 0, и негативна връзка - появата на НЛР няма връзка с лекарството - 0. При 13 от общо 15 пациенти в групата с АС установихме НЛР, в т.ч. са и регистрираните отклонения в лабораторните изследвания. Само двама пациенти в групата с AC не съобщават за НЛР. При тях липсват и отклонения в проведените лабораторни изследвания, които да се приемат за НЛР.

Анализ на резултатите при пациенти с РА. Демографските показатели са анализирани по идентичен начин (таблица 2). Групата с РА включва 20 пациенти - 14 пациенти, от които 2 мъже и 12 жени са наблюдавани и проследени за пълен едногодишен период. При двама пациенти лечението продължава само 6 месеца: при първия пациент се наложи замяна на едно биологично лекарство с друго след 6-ия месец поради незадоволителен терапевтичен отговор, а при втория лечението бе прекратено поради продължително отсъствие от страната. При трима пациенти лечението бе прекратено поради изява на сериозна НЛР. Един пациент е с изключващ критерий и не е проследяван. Анализът на демографските показатели показва, че жените са 6 пъти повече от мъжете, като това е характерно за две от възрастовите групи. В групата 18-45 г. има само 1 мъж и 1 жена. Средната възраст на мъжете с РА, завършили проучването, е 49,5 г., докато средната възраст на жените с РА, завършили проучването, е с 10 години повече - 59,4 г.
We assessed the relation of ADRs with the treatment received, as follows: Certain (casual connection) - 5; Probable/Likely relation - the drug is associated with the onset of ADR, but there is no reproducibility of laboratory data -51 ; Possible relation - there is a temporary relation between the drug and ADR - 18; Unlikely - ADR occurs during the administration of the drug, but the reason is different - 0; Unassessable/Unclassifiable relation the onset of ADR is not associated with the drug - 0 . We found ADRs in 13 out of a total of 15 patients in the AS group, including registered deviations in the laboratory tests. Only two patients in the AS group did not report any ADRs. They had no deviations in the laboratory tests, which could be considered ADRs.

Analysis of results in patients with RA. Demographic data were analyzed in the same way (Table 2). The RA group included 20 patients - 14 patients, of them 2 men and 12 women were observed and followed up for a full 1-year period. Two patients had treatment for only 6 months: the first patient required a switch to another biological medicine after the 6th month due to unsatisfactory therapeutic response, and the treatment of the second patient was discontinued due to his continuous absence from the country. In three patients, the treatment was discontinued due to the onset of a serious ADR. One patient had exclusion criteria and was not followed up. The analysis of the demographic parameters shows that women are 6 times more than men, and this is observed in both age groups. In the 18-45 age group, there was only 1 man and 1 woman. The average age of the men with RA, who completed the study, was 49.5, whereas the average age of the women with RA, who completed the study, was 10 years more -59.4 . 
Пациентите в групата с РА са провеждали лечение с 5 лекарствени продукта - etanercept, adalimumab, golimumab, certolizumab pegol и rituximab. Най-голям дял заема групата с adalimumab, а най-малък е делът на наблюдаваните пациенти на лечение с certolizumab pegol и rituximab. НЛР по MedDRA и тяхното честотно разпределение са представени на фиг. 5.

Общият брой на съобщените и потвърдени НЛР е 67 (фиг. 6). От тях сериозни НЛР - 3, от които 1 НЛР отговаря на дефиницията за SUSAR, а другите 2 попадат в групата на подозираните; неочаквани са 15; а подозирани - 51.
The patients in the RA group received treatment with 5 medicinal products - Etanercept, Adalimumab, Golimumab, Certolizumab pegol, and Rituximab. The Adalimumab group had the largest share, and the smallest share was seen in the observed patients receiving Certolizumab pegol and Rituximab. ADRs under MedDRA and their incidence distribution are presented in Fig. 5.

The total number of reported and confirmed ADRs were 67 (Fig. 6). There were 3 serious ADRs, of which 1 ADR met the definition of SUSAR, and the other 2 fell into the group of suspected ADRs; there were 15 unexpected ADRs and 51 suspected ADRs.

\section{Таблица 2. Демографски данни на пациенти с РА}

\section{Table 2. Demographic data of patients with RA}

\begin{tabular}{|c|c|c|c|}
\hline Parameters & Men $\mathrm{n}-2$ & Women $\mathrm{n}-12$ & Total $\mathrm{n}-14$ \\
\hline Age $18-45$ years & $1(7.1 \%)$ & $1(7.1 \%)$ & $2(14.2 \%)$ \\
\hline Age $46-65$ years & $1(7.1 \%)$ & $6(42.9 \%)$ & $7(50.0 \%)$ \\
\hline Age $\uparrow 65$ years & - & $5(35.8 \%)$ & $5(35.8 \%)$ \\
\hline Number & $2(14.2 \%)$ & $12(85.8 \%)$ & $14(100.0 \%)$ \\
\hline Average & 49.5 & 59.4 & 58.0 \\
\hline Median1 & - & 64.0 & 62.0 \\
\hline Mode1 & - & 63.0 & 60.0 \\
\hline Standart deviation & 11.4 & 11.6 & 12.3 \\
\hline
\end{tabular}

Поради нисък брой на мъжете параметри не са изчислени

Due to the low number of men, median and mode are not calculated
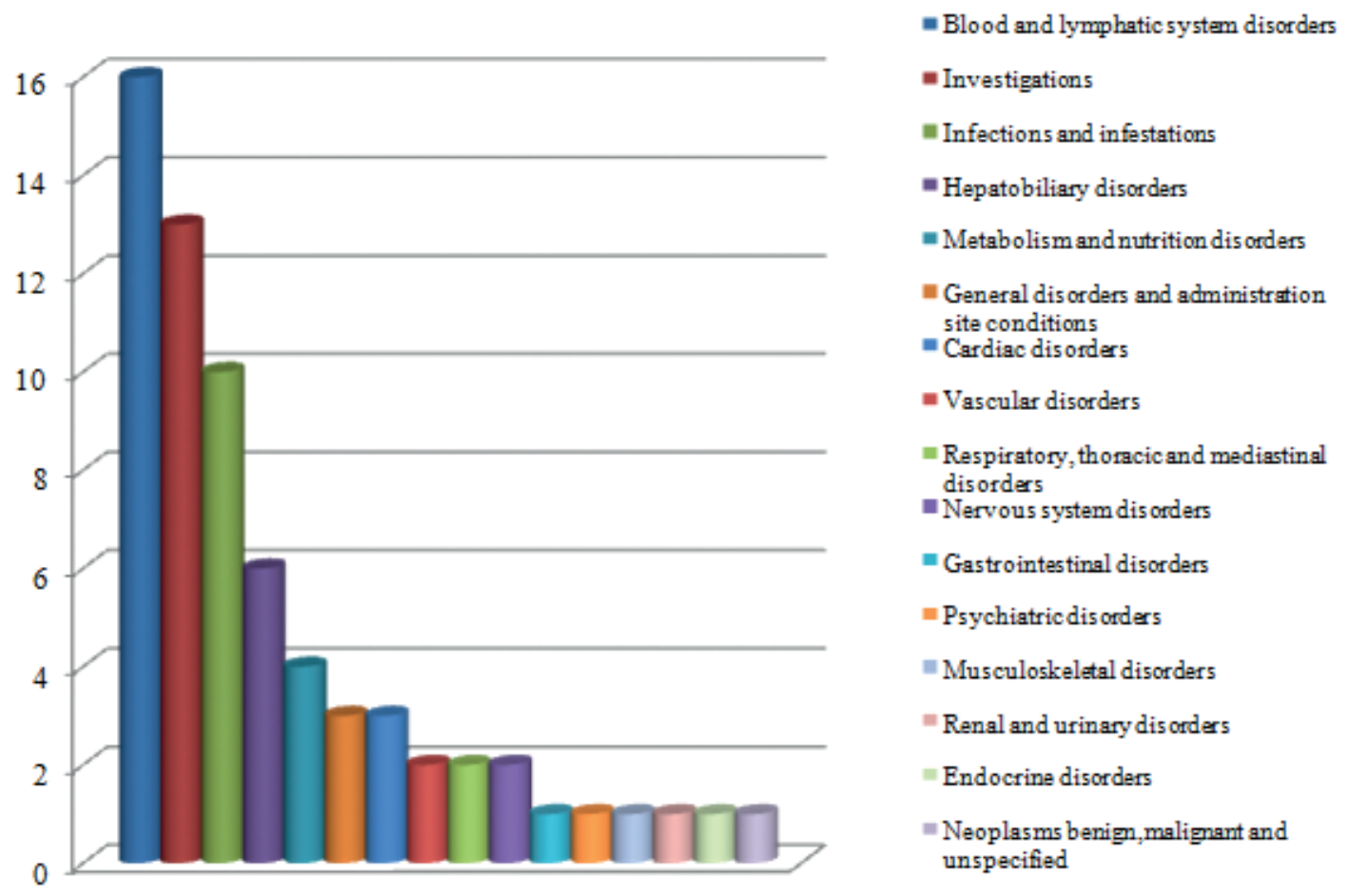

Фие. 5. НЛР, класифицирани по системо-органната класификация по MedDRA, версия 12.0

Fig. 5. ADRs systematized according to MedDRA System Organ Class, version 12.0 


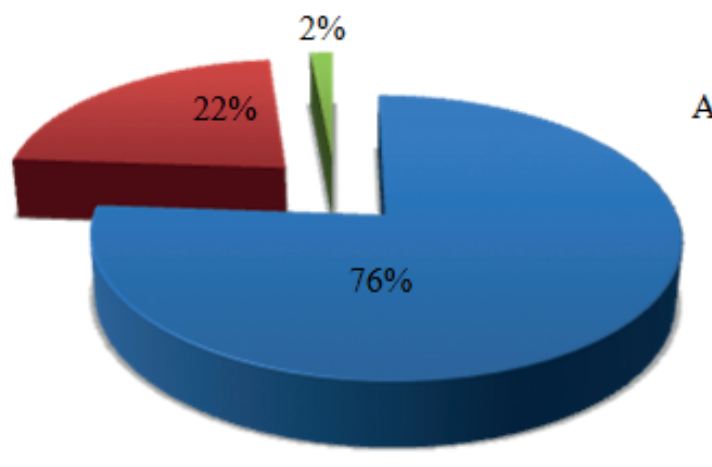

ADRs - total number 67

$\square$ Suspected - 51

Unexpected - 15

$\square$ SUSAR - 1
Фие. 6. Видове НлР

Fig. 6. Types of ADRs
Връзката на НЛР с провежданото лечение е следната: сигурна връзка - 4; вероятна връзка - 32; възможна връзка - 30; съвпадение - 1; негативна връзка - 0. В групата с РА при всички пациенти установихме НЛР, в т.ч. и отклонения в проведените лабораторни изследвания, които приемаме също за НЛР.

Анализ на резултатите при пациенти с ПсА. Демографските показатели са представени в таблица 3.

Пациентите в групата с ПсА са провеждали лечение с 2 продукта - 3 c etanercept и 3 с adalimumab. НЛР са систематизирани по системо-органни класове и честотно им разпределение е показано на фиг. 7.

Общият брой на съобщените и потвърдени НЛР е 19 (фиг. 8). От тях: сериозни НЛР (довели до отпадане от проучването) - 2, от които 1 НЛР отговаря на дефиницията за SUSAR, а другата попада в групата на подозираните; неочаквани - 6; подозирани - 12. Само при един пациент в групата с ПсА не установихме НЛР.
The relation of ADRs with the treatment received is as follows: Certain (casual connection) - 4; Probable relation - 32; Possible relation - 30; Unlikely - 1; Unassessable/Unclassifiable relation -0 . We found ADRs in all patients in the RA group, including registered deviations in the laboratory tests, which we also considered ADRs.

Analysis of results in patients with PsA. Demographic data are presented in Table 3.

The patients in the PsA group received treatment with 2 products -3 patients were treated with Etanercept, and 3 patients were treated Adalimumab. ADRs are systematized according to system-organ classes, and their incidence distribution is presented in Fig. 7.

The total number of reported and confirmed ADRs is 19 (Fig. 8). There were 2 serious ADRs (leading to withdrawal from the study), of which 1 ADR met the definition of SUSAR, and the rest fell into the group of suspected ADRs; Unexpected ADRs - 6; Suspected ADRs - 12. We did not find any ADRs only in one patient in the PsA group.

Таблица 3. Демографски данни на пациенти с ПсА - пол и възраст

Table 3. Demographic data of patients with PsA - sex and age

\begin{tabular}{|c|c|c|c|}
\hline Parameters & Men $\mathbf{n}-\mathbf{4}$ & Women $\mathbf{n - 2}$ & Total $\mathbf{n}-\mathbf{6}$ \\
\hline Age 18-45 years & $1(16.66 \%)$ & $0(0.0 \%)$ & $1(16.66 \%)$ \\
\hline Age 46-65 years & $2(33.33 \%)$ & $2(33.33 \%)$ & $4(66.67 \%)$ \\
\hline Age $\uparrow$ 65 years & $1(16.66 \%)$ & $0(0.0 \%)$ & $1(16.66 \%)$ \\
\hline Number & $4(66.67 \%)$ & $2(33.33 \%)$ & $6(100.0 \%)$ \\
\hline Average & 51.5 & 50.0 & 51.0 \\
\hline Median1 & 61.0 & - & 59.0 \\
\hline Mode1 & 56.0 & - & 56.0 \\
\hline Standart deviation & 15.5 & 15.0 & 15.25 \\
\hline
\end{tabular}

Поради нисък брой на жените, median и mode не са изчислени

Due to the low number of women, median and mode are not calculated 


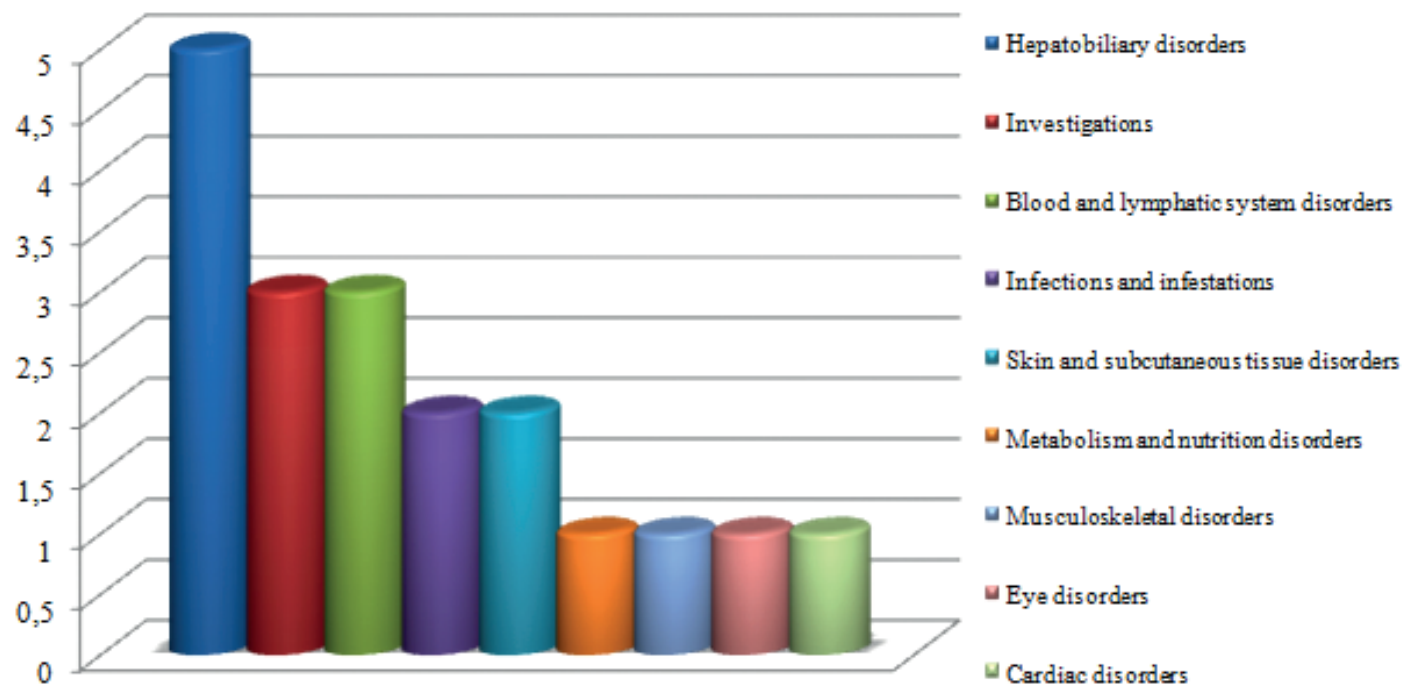

Фuе. 7. НЛР по системо-органната класификация по MedDRA, версия 12.0

Fig. 7. ADRs systematized according to MedDRA System Organ Class, version 12.0

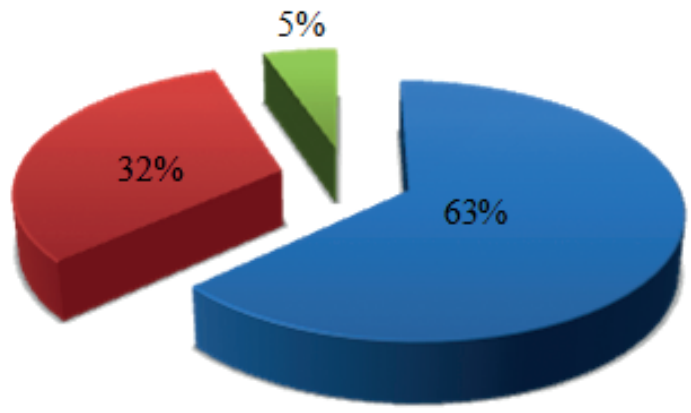

- Suspected - 12

Unexpected - 6

$\square$ SUSAR - 1

Фие. 8. Видове НЛР

Fig. 8. Types of ADRs

Обобщение на резултатите от проспективното проучване. Adalimumab и etanercept ca най-предписваните БЛП в България и заемат дял от $77 \%$ от общото предписание на БЛП, а останалите продукти заемат дял от $23 \%$.

Систематизирани по MedDRA, HЛP са представени с относителните си дялове на фиг. 10. Първите 5 по честота НЛР са: 1. Нарушения на кръвта и лимфната система - 35 случая; 2. Инфекции и инфестации - 24 случая; 3. Изследвания - 19 случая; 4. Хепатобилиарни нарушения - 18 случая, и 5. Общи нарушения и ефекти на мястото на приложение - 11 случая.

Общият брой на съобщените и потвърдени НЛР е 160 (фиг. 11). От тях 3 НЛР отговарят на дефиницията за SUSAR; неочаквани - 30; подозирани - 127.
Summary of the prospective study. Adalimumab and Etanercept are the most prescribed BMPs in Bulgaria and have a share of $77 \%$ of the total prescription of BMPs; the share of the rest of the products is $23 \%$.

ADRs systematized under MedDRA are presented in Fig. 10 with their relative shares. The first 5 most frequent ADRs were 1. Blood and lymphatic system disorders - 35 cases; 2 . Infections and infestations - 24 cases; 3. Investigations - 19 cases; 4. Hepatobiliary disorders - 18 cases, and 5. General disorders and administration site conditions - 11 cases.

The total number of the reported and confirmed ADRs were 160 (Fig. 11). 3 ADRs meet the definition of SUSAR; Unexpected ADRs - 30; Suspected ADRs - 127 . 


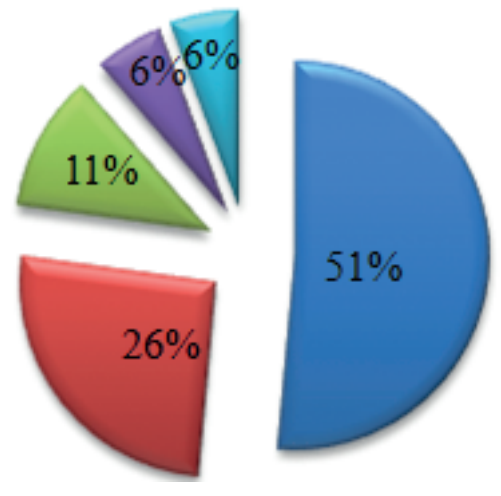

Gumira - 18

Enbrel - 9

$\square$ Simponi - 4

罗 Cimzia - 2

Mabthera - 2
Фиг. 9. Разпределение на пациентите по вид БЛП, използван за лечение

Fig. 9. Distribution of patients by type of BMP used for treatment
System-organ class MedRA - Relative share
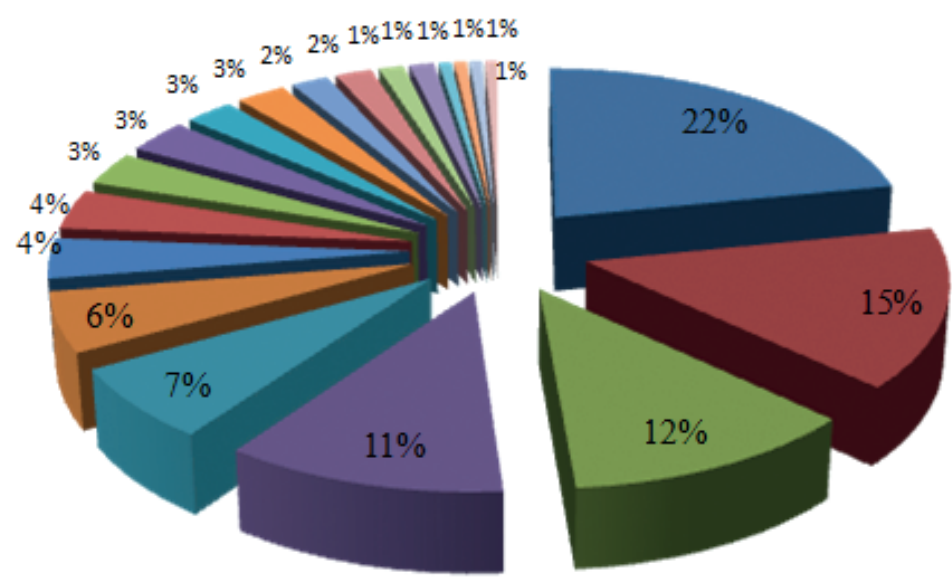

"Blood and lymphatic system disorders

$=$ Infections and infestations

$=$ Investigations

- Hepatobiliary disorders

= General dis orders and administration site conditions

= Metabolismandnutrition dis orders

= Cardiac dis orders

- Psychiatric dis orders

= Vascular disorders

= Skin and subcutaneous tis sue disorders

= Respiratory, thoracic and mediastinal disorders

= Gastrointestinal disorders

= Nervous system dis orders

= Musculoskeletal disorders

$=$ Ear and labyrinth disorders

= Eye dis orders

" Renal and urinary dis orders

= Endocrine disorders

"Neoplasms benign,malignant and unspecified

$=$ Injury, poisoning and complications

resulting from interventions

Фие. 10. Относителен дял на НЛР по системо-органни класове

Fig. 10. Relative share of ADRs by System-Organ Class

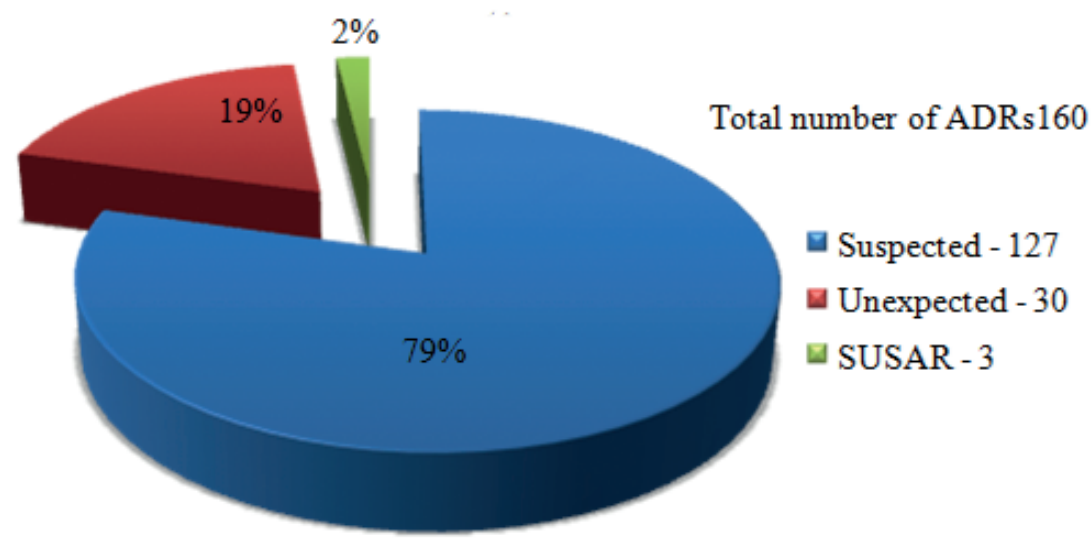

Фие. 11. Видове НЛР

Fig. 11. Types of ADRs 
На фриг. 12 представяме обобщени данни за брой НЛР за трите заболявания и тяхното разпределение според степента им на тежест по CTCAE (version 4.03, June 14, 2010). Най-голям относителен дял заемат НЛР със степен на тежест 1 и 2, като 1 степен са $63 \%$.

Връзката на НЛР с провежданото лечение (фиг. 13) е следната: сигурна връзка - 10; вероятна връзка - 92; възможна връзка - 56; съвпадение - 2; негативна връзка - 0 .

В таблица 4 и фиг. 14 представяме обобщени данни за абсолютния брой и относителните дялове на НЛР при пациентите в трите групи анализирани заболявания (АС, РА и ПсА), проследени в проспективното проучване.

Установява се много висока честота на НЛР, несъответно по-висока в сравнение с предрегистрационните данни. Най-висока е честотата в групата пациенти с AC - 4,35 НЛР на пациент. Общата честота на НЛР в цялото проспективно проучване се измерва на 4 НЛР/пациент.
The summarized data of the number of ADRs of the three diseases and their distribution by a degree of severity under CTCAE (version 4.03, June 14 2010) are presented in Fig. 12 ADRs with grade 1 and 2 severity had the greatest relative share, and grade 1 severity had $63 \%$.

The relation between ADR and the treatment received (Fig. 13) was as follows: Certain (casual connection) - 10; Probable relation - 92; Possible relation - 56; Unlikely - 2; Unassessable/Unclassifiable - 0 .

Table 4 and Fig. 14 present the summarized data of the absolute number and relative shares of ADRs in the patients in the three groups of analyzed diseases (AS, RA and PsA) followed up in the prospective study.

Obviously, the incidence of ADRs was found to be very high and disproportionately higher than the pre-authorization data. The highest incidence was found in the AS group - 4.35 ADR/patient. The total ADR incidence in the entire prospective study was measured at $\sim 4$ (four) ADRs/patient.

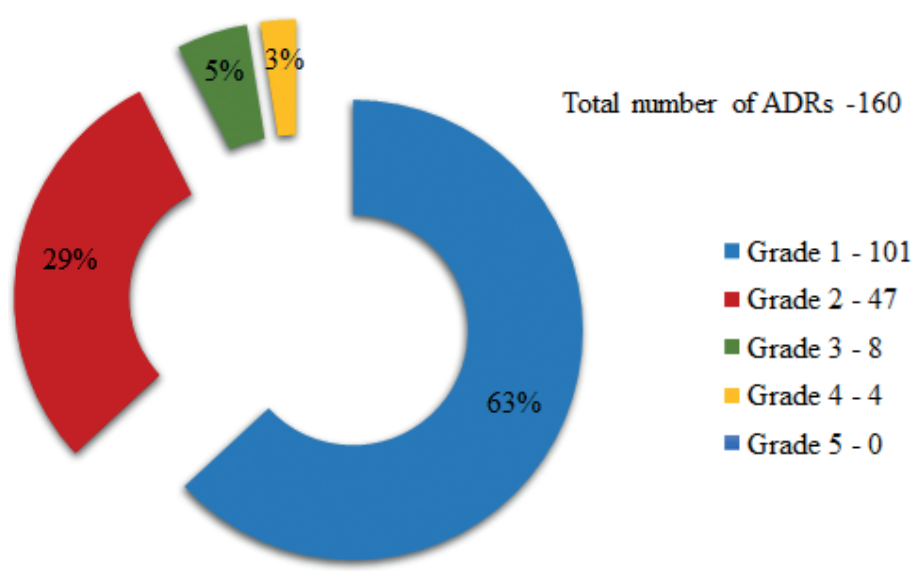

Фие. 12. Степен на тежест на НЛР

Fig. 12. Grades of the severity of ADRs

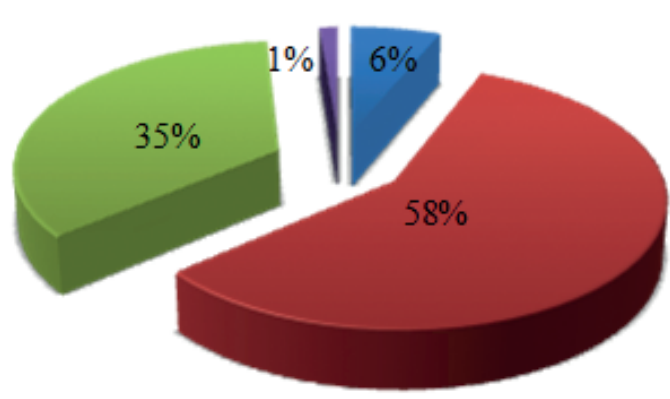

Total number of ADRs - 160

$\square$ Certain (casual connection) - 10

a Probable - 92

Mossible -56

Unlikely -2

Unassessable/Unclassifiable - 0

Фие. 13. Видове връзки между лечение и НЛР

Fig. 13. Types of relations between treatment and ADRs 
Таблица 4. Установени НЛР в трите групи анализирани заболявания

Table 4. ADRs identified in the three groups of analyzed diseases

\begin{tabular}{|c|c|c|c|}
\hline Disease & Number of patients & ADRs & Relative share \\
\hline AS & 17 & 74 & 4,35 ADRs/patient \\
\hline RA & 17 & 67 & 3,94 ADRs/patient \\
\hline PsA & 8 & 19 & 2,38 ADRs/patient \\
\hline Total & 42 & 160 & 3,80 ADRs/patient \\
\hline
\end{tabular}

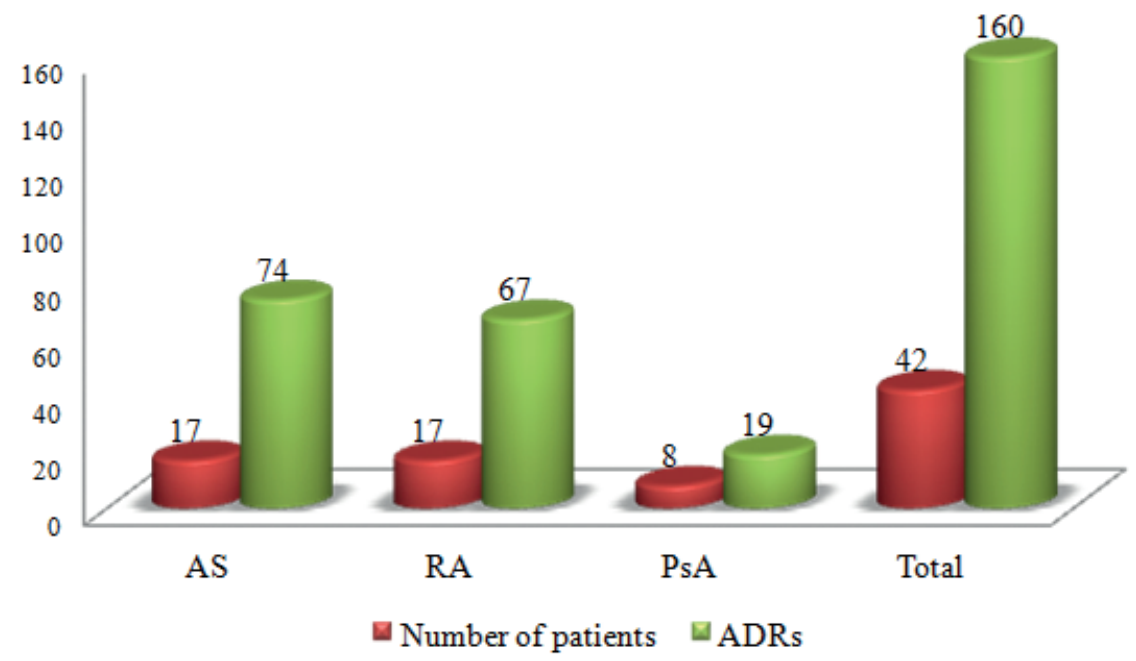

Фие. 14. Обобщени данни за установените НЛР в трите групи анализирани заболявания

Fig. 14. Summarized data of ADRs identified in the three groups of analyzed diseases

\section{ОБсъжданЕ}

Демографрската характеристика на включените в проспективното проучване пациенти отговаря на епидемиологичните данни за България, типична е за българската популация и съответства на данните за европеидната раса.

Adalimumab и etanercept са най-предписваните БЛП в България и заемат дял от $77 \%$ от общото предписание на биологични продукти, а останалите продукти заемат дял от $23 \%$.

Дельт на пациентите с РА, провеждали монотерапия, е 29,4\% (5 от 17 пациенти), а при пациентите с ПсА - $75 \%$ (6 от 8 пациенти), или $44 \%$ от всички болни са провеждали монотерапия.

Установихме много висок относителен дял - 17,0\%, на изява на сериозни НЛР, довели до прекратяване на лечението. Проспективно установената честота на НЛР е 3,80/пациент. Този резултат извежда честотата на идентифицираните НЛР като много чести по системо-органната класификация по MedDRA.

\section{Discussion}

The demographic characteristics of the patients included in the prospective study correspond to the epidemiological data for Bulgaria. They are typical of the Bulgarian population and consistent with the data of the Caucasian race.

Adalimumab and Etanercept are the most prescribed BMPs in Bulgaria and have a share of $77 \%$ of the total prescription of BMPs; the share of the rest of the products is $23 \%$.

The share of the patients with RA, who had monotherapy, was $29.4 \%$ (5 of 17 patients), and the share of the patients with PsA was $75 \%$ (6 of 8 patients), or $44 \%$ of all patients, who had monotherapy.

We found a very high relative share of $17.0 \%$ of onset of serious ADRs, which led to discontinuation of treatment. The incidence of the prospectively identified ADRs was 3.80 /patient. This result demonstrates the very high incidence of the identified ADRs, according to MedDRA System Organ Class. 
Ако към броя на прекратените случаи на лечение поради НЛР добавим и случаите на преустановяване на лечението поради други причини, то относителният дял на случаите в проспективното проучване, при които биологичното лечение е преустановено, е 25,5\%, дял, който е $1 / 4$ от общия брой пациенти и е относително по-висок в сравнение с предрегистрационните данни.

С най-висока честота са хепатобилиарните нарушения, нарушенията на кръвта и лимфната система, инфекциите и инфестациите и отклоненията в изследванията.

\section{Изводи}

Проактивното търсене, мониториране и анализиране на НЛР чрез активното участие на лекарите в проследяването на лекарствената безопасност и същевременно инфоомиран избор и сътрудничество на пациентите са същностен подход при провеждане на биологично лечение и гарантира неговия успех.

Провеждането на монотерапия с БЛП пред комбинираното им приложение с метотрексат е съществено отклонение от установените стандарти на EULAR за лечение на възпалителни ставни заболявания с биологични лекарства [21-29].

Най-честата причина за преустановяване на биологичната терапия при болните с възпалителни ставни заболявания е изявата на НЛР.

Болните с възпалителни ставни заболявания, лекувани с БЛП, трябва да бъдат проследявани стриктно за следните НЛР: хепатобилиарни нарушения, нарушения на кръвта и лимфнната система и инфекции и инфестации.

При проследените от нас пациенти биологичната терапия не повишава риска от неоплазми за разлика от някои европейски проучвания в тази насока [30].

Пациентите с възпалителни ставни заболявания, показани за биологична терапия, трябва да бъдат запознати със същността на болестта, механизма на действие на БЛП, необходимостта от активно проследяване за отклонения по предварително зададени критерии. Така те ще участват активно в процеса на лечението, оценката на терапевтичната ефеективност и съобщаването на НЛP [31].
If we complete the number of the cases of treatment discontinuation due to ADR with the number of cases of treatment discontinuation for any other reason, the relative share of the cases of discontinuation of the biological treatment in the prospective study is $25.5 \%$, which share constitutes $1 / 4$ of the total number of patients and is relatively higher compared to the pre-authorization data.

The highest incidence was seen in the hepatobiliary disorders, blood and lymphatic system disorders, infections and infestations, and deviations in the tests.

\section{Conclusions}

Proactive search, monitoring, and analysis of ADRs, through doctors' active participation in pharmacovigilance and the informed choice and cooperation of the patients, at the same time, is an essential approach in the administration of biological treatment and ensures its success.

Administration of monotherapy with BMPs, considering their combined use with Methotrexate, is a significant deviation from the established EULAR standards of treatment of inflammatory joint diseases with biological medicines [21-29].

The most common reason for discontinuation of the biological therapy in patients with inflammatory joint diseases is the onset of ADRs.

Patients with inflammatory joint diseases treated with BMPs must be monitored for the following ADRs regularly: hepatobiliary disorders, blood, and lymphatic system disorders, and infections and infestations.

Biological therapy in the patients we followed up did not increase the risk of neoplasms, compared to the results of some European studies in this area [30].

Patients with inflammatory joint diseases eligible for biological therapy must be provided with information on the nature of the disease, BMP mechanism of action, and the necessity of active monitoring for deviations from the preset criteria. Thus, they will take an active part in the process of treatment, assessment of therapeutic effectiveness, and ADR reporting [31]. 


\section{Библиография / References}

1. European Medicines Agency. European public assessment reports. [Cited 2019 February 10]. http://www.ema.europa. eu/ema/index.jsp?curl = pages $/$ medicines/landing/epar_ search.jsp\&mid = WC0b01ac058001d124.

2. Parvova I, Stoilov R, Hristov E. Similar biological medicinal products-application in rheumatology. Revmatologiia (Bulgaria), 2015, 22 (1), 3-16.

3. European Medicines Agency. [Cited 2019 February 10]. https:// www.ema.europa.eu/en/human-regulatory/research-development/scientific-guidelines/biological-guidelines

4. Regulation (EC) No 726/2004 of the European Parliament and of the Council of 31 March 2004 laying down Community procedures for the authorisation and supervision of medicinal products for human and veterinary use and establishing a European Medicines Agency. Official Journal of the European Union. [Cited 2016 June 30]. http://data.europa.eu/eli/ reg/2004/726/oj

5. European Medicines Agency. Guideline on similar biological medicinal products. [Cited 2016 June 30]. http://www.ema. europa.eu/docs/en_GB /document_library/Scientific_guideline/2014/10/WC500176768.pdf.

6. European Commission. Pharmacovigilance. [Cited 2016 May 15]. http://ec.europa.eu/health/human-use/pharmacovigilance/index_en.htm.

7. Закон за здравето (в сила от 01.01.2005 г. Lex.bg. [Cited 2015 June 30]. http://www.lex.bg/bg/laws/ Idoc/2135489147.

8. Закон за лекарствените продукти в хуманната медицина (в сила от 13.04.2007 г.) [Cited 2015 June 30]. Lex.bg. http://www.lex.bg/bg/laws/ldoc/2135549536.

9. World Medical Association - Declaration of Helsinki - ethical principles for medical research involving human subjects. [Cited 2015 June 30]. Available from: https://www.wma. net/policies-post/wma-declaration-of-helsinki-ethical-principles-for-medical-research-involving-human-subjects/

10. ICH E6 Good Clinical Practice (GCP) Guideline [Cited 2015 June 30]. https://www.ich.org/products/guidelines/efficacy/ efficacy-single/article/integrated-addendum-good-clinical-practice.html

11. Guideline for good clinical practice. E6(R2) EMA/CHMP/ ICH/135/1995 [Cited 2015 June 30]. https://www.ema.europa.eu/en/documents/scientific-guideline/ich-e-6-r1-guideline-good-clinical-practice-step-5_en.pdf

12. International Society of Pharmacoepidemiology. ISPE Commentary - Guidelines for good pharmacoepidemiology practices (GPP) Pharmacoepidemiology and drug safety 2008; 17: 200-208 doi: 10.1002/pds. 1471.

13. American College of Rheumatology, Subcommittee on Rheumatoid Arthritis Guidelines. Guidelines for the management of rheumatoid arthritis: 2002 update. Arthritis Rheum 2002;46:328-346.

14. Ritter JM, Lewis D, Mant TG, Ferro A. A Textbook of Clinical Pharmacology and Therapeutics. Hodder Arnold, UK; 2008.

15. Lee DM, Weinblatt ME. Rheumatoid arthritis. Lancet 2001;358:903-911.
16. Smolen JS, Aletaha D, Koeller M et al. New therapies for treatment of rheumatoid arthritis. Lancet 2007;370:18611874.

17. Ward M, Deodhar A, Akl A, et al. American College of Rheumatology/Spondylitis Association of America/Spondyloarthritis Research and Treatment Network 2015 Recommendations for the Treatment of Ankylosing Spondylitis and Nonradiographic Axial Spondyloarthritis. Arthritis \& Rheumatology, doi 10.1002/art.39298 @2015, American College of Rheumatology.

18. Tillett W, Jadon D, Costa $L$, et al. The Classification for Psoriatic Arthritis (CASPAR) criteria - a retrospective feasibility, sensitivity, and specificity study. J Rheumatol 2012;39:154-6. doi:10.3899/jrheum. 110845 .

19. National health insurance fund (NHIF). Bulgaria. [Cited 2016 May 15]. Available from: https://www.nhif.bg/page/45.

20. National Cancer Institute (NCI). Common Terminology Criteria for Adverse Events (CTCAE version 4.03, June 14, 2010). [Cited 2014 June 30]. Available from: https://ctep.cancer.gov/ protocoldevelopment/electronic_applications/ctc.htm

21. MedDRA. System Organ Class of MedDRA version 12.0 [Cited 2014 June 30]. Available from: https://www.meddra.org/ how-to-use/support-documentation/english.

22. Gossec L, Smolen JS, Ramiro S, et al. European League Against Rheumatism (EULAR) recommendations for the management of psoriatic arthritis with pharmacological therapies: 2015 update. Ann Rheum Dis. Published online: 07 December 2015. doi:10.1136/annrheumdis-2015-208337.

23. Smolen JS, Landewé R, Breedveld FC, et al. EULAR recommendations for the management of rheumatoid arthritis with synthetic and biological disease-modifying antirheumatic drugs: 2013 update Ann Rheum Dis. Published online: 25 October 2013. doi:10.1136/annrheumdis-2013-204573.

24. Ramiro S, Gaujoux-Viala C, Nam JL, et al. Safety of synthetic and biological DMARDs: a systematic literature review informing the 2013 update of the EULAR recommendations for management of rheumatoid arthritis. Ann Rheum Dis 2014;73:529-535.

25. Smolen JS, Landewé R, Bijlsma J, et al. EULAR recommendations for the management of rheumatoid arthritis with synthetic and biological disease-modifying antirheumatic drugs: 2016 update. Ann Rheum Dis. Published online: 06 March 2017. doi:10.1136/annrheumdis-2016-210715.

26. Van der Heijde D, Ramiro S, Landewé R et al. 2016 update of the ASAS-EULAR management recommendations for axial spondyloarthritis. Ann Rheum Dis. 2017;76:978-991.

27. Taylor W, Gladman D, Helliwell P et al. Classification criteria for psoriatic arthritis: development of new criteria from a large international study. Arthritis Rheum 2006;54:2665-73.

28. Parvova I, Hristov E, Rashkov R, Getov I. Significance of concomitant use of methotrexate for efficacy, safety and immunogenics of the biological treatment for rheumatoid arthritis. Revmatologiia (Bulgaria), 2015;23 (2),42-51. 
29. Putte LB, Atkins C, Malaise M et al. Efficacy and safety of adalimumab as monotherapy in patients with rheumatoid arthritis for whom previous disease modifying antirheumatic drug treatment has failed. Ann Rheum Dis 2004;63:508-516.

30. Carmona, L, Abasolo, L, Descalzo, MA et al. Cancer in patients with rheumatic diseases exposed to TNF antagonists.

Постъпил за печат: 20.01.2020 2.

$\triangle$ Автор за кореспонденция:

Д-р Ива Първова, дм

Клиника по ревматология

УМБАЛ "Свети Иван Рилски"

ул. "Урвич" № 13

1612 София, България

тел: +35929582281

e-mail: ivaparvova@mail.bg
BIOBADASER Study Group. EMECAR Study Group. // Seminars in Arthritis \& Rheumatism, 2011, 41(1):71-80.

31. Parvova I, Hristov E, Rashkov R, Getov I. Retrospective study of adverse drug reaction in bulgarian population of patient with inflammatory joint diseases treated with biological medicinal products Revmatologiia (Bulgaria), 2016;24(1),17-18. $\triangle$ Corresponding author:

Iva Parvova, MD

Clinic of Rheumatology

University Hospital "Sveti Ivan Rilski"

13 Urvich str.

1612 Sofia, Bulgaria

тел: +35929582281

e-mail: ivaparvova@mail.bg 